Article

\title{
Technology and Higher Education: A Bibliometric Analysis
}

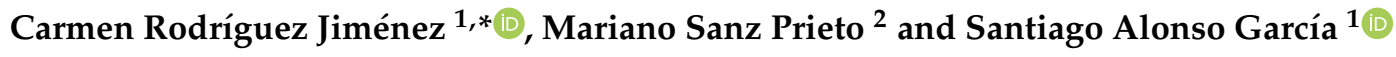 \\ 1 Department of Didactics and School Organisation, University of Granada, 18071 Granada, Spain \\ 2 Department of Didactics and Theory of Education, Universidad Autónoma de Madrid, 28049 Madrid, Spain \\ * Correspondence: rodri96@correo.ugr.es
}

Received: 14 June 2019; Accepted: 28 June 2019; Published: 3 July 2019

\begin{abstract}
Technology in education is one of the current realities that generates most interest. The objective of this research is to analyze the scientific production of educational technology in the higher education stage, within the Web of Science database. To carry out this study, a bibliometric study was conducted, which first established the keywords that would govern the rest of the research and continued with the analysis of different variables that addressed different features, from the origin of the archives to the authors or the most prolific and relevant institutions in the scientific community. The results indicate that there has been a significant increase in publications on this subject in recent years, and as evident from the current peak, this is a growing trend that will lead to more research in the coming years.
\end{abstract}

Keywords: educational technology; higher education; bibliometrics

\section{Introduction}

Today, we are witnessing the consolidation and expansion of technology as an essential and constant element in education. The popularity [1] and the facilities or elements [2,3] that the use of these technologies [4] incorporates into Teaching-Learning (T-L) processes cause more and more teachers to bet on the implementation of technologies in classrooms at any educational level.

It is, therefore, necessary to establish frameworks of reference to know which technologies are applied to education or educational technology as well the role of teachers and how they should be trained to employ such technologies in teaching $[5,6]$.

Regarding the role of teachers in this new digital context, it is important to refer to the initial training that these teachers receive at university, which leads to the question of how to manage and implement technology that is designed to be employed in higher education.

Numerous research studies $[7,8]$ have indicated that using technology in the classroom fosters participation, collaboration between teachers and learners, the creation of original content, or the adaptation and use of other sources found on the internet, among many other things. For current and future generations, technologies are not "new" [9], a term used until recently to refer to them [10], but something they coexist with. So, the challenge is not to know or manage them, but to take advantage of them and make efficient and effective use of them [11]. In this case, teachers or people who are being trained to be teachers must acquire the necessary theoretical and practical knowledge to be digitally competent [12].

In the higher education stage, especially if the focus is on those degrees that train future teachers, the presence of technology should be constant, since innovation-as the engine of quality education-includes such technology. On the other hand, studies indicate that even today many teachers are reluctant to implement technology in the classroom $[13,14]$. This, therefore, exposes the need to further research the causes behind or reasons why there is still such resistance. 
In recent years, there have been publications in the field of educational research with the aim of analyzing the number of studies on a specific theme or element $[15,16]$. Moreover, as is promulgated throughout this article, the theme of technology is a constant in many of them [17-19]. On the other hand, there are research works of the same nature that approach educational technology like this one, relating it to educational stages $[20,21]$.

Following the presentation of all the above considerations, this study seeks to reveal the influence that educational technology is having so far on the field of higher education and, in particular, on scientific literature.

\section{Materials and Methods}

The present study follows the structure of bibliometric studies, as previously marked by other investigations of the same court [22,23]. That is, the production of research in a specific field on a specific topic is studied and evaluated [24].

As far as our study is concerned, the literature search took place during the second quarter of 2019 and was carried out in the Web of Science database, due to its rigor and prestige in both scientific and international literature. This database contains one of the greatest influential scientific productions and offers many possibilities in terms of delimiting and limiting searches carried out within the platform.

The procedure for the preparation of the final sample obtained $(n=1689)$ began with the choice of the keywords used to perform that search. Thus, the two key concepts chosen were "Higher Education" and "Educational Technology", both included in the ERIC (Education Resources Information Center) thesaurus. The connector used to carry out the search with both concepts was "and", with the purpose of finding documents that either in their title, summary, keywords, or body of text contain the terms that were studied in the present research. In addition, a search was carried out in all the categories in this database because, although the nature of the present study is educational, the interest in analyzing the scientific production on this subject covers all fields of knowledge.

Below are the inclusion and exclusion criteria used to obtain the final sample with the key concepts mentioned previously (Table 1):

Table 1. Inclusion and exclusion criteria used in the bibliometric analysis.

\begin{tabular}{cc}
\hline Inclusion Criteria & Exclusion Criteria \\
\hline Use of educational technology in higher education & Use of the subject educational technology at any other educational stage \\
Production up to 2018 & Year 2019, as the year is not yet complete \\
Web of Science main collection & Other databases \\
\hline
\end{tabular}

Note: own production.

After choosing the inclusion and exclusion criteria, we proceeded to define the objectives and indicators that led to this investigation in order to respond to all of the above. The choice of metadata presented below (Table 2) was extracted from the analysis of other studies with a similar nature [25-27]:

Table 2. Objectives and indicators of the investigation.

\begin{tabular}{|c|c|c|}
\hline & Objective & Indicators \\
\hline (A) & Evolution and productivity of the area & $\begin{array}{l}\text { 1. Diachronic productivity } \\
\text { 2. Price's law }\end{array}$ \\
\hline (B) & Characteristics of publications and dispersion of production & $\begin{array}{l}\text { 3. Types of publications } \\
\text { 4. Bradford's law } \\
\text { 5. More productive journals on the subject }\end{array}$ \\
\hline (C) & Productivity of authors and institutions & $\begin{array}{l}\text { 6. More prolific authors } \\
\text { 7. More prolific institutions } \\
\text { 8. Connections between descriptors }\end{array}$ \\
\hline
\end{tabular}

Note: own production. 


\section{Results}

\subsection{Evolution and Productivity of the Area}

Within this block, diachronic productivity and Price's law are the main axes. Thus, Figure 1 shows how the literature has been distributed from its beginning in 1972 until 2018. It can be observed that last year's production alone, reaching 226 documents, represents $13.36 \%$ of the total scientific production in 32 years.

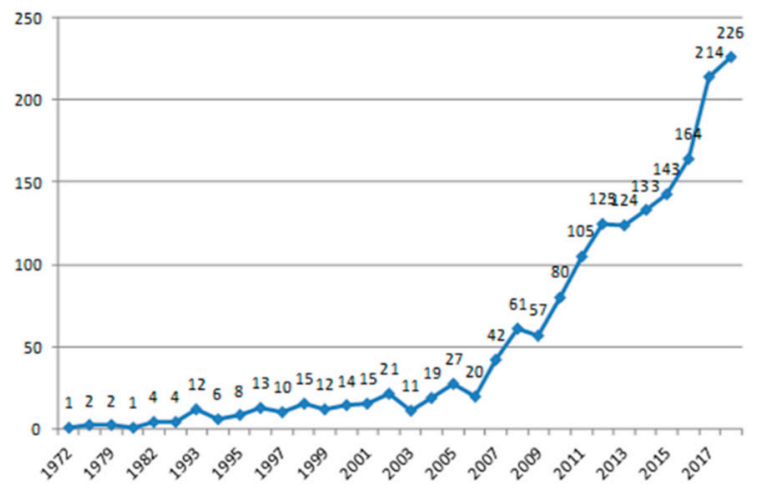

Figure 1. Diachronic productivity of educational technology in higher education since 1972. Note: own production.

In this figure, we can see how diachronic productivity has increased since the beginning of the 21st century. Despite slight declines in a few years, such as 2003, 2006, and 2008, it began to grow considerably, reaching its highest point in 2018. This fact seems to indicate that if the trend continues, production will continue to increase in the coming years.

On the other hand, there are several bibliometric laws, among which is Price's law [28], that suggest that scientific information grows so quickly that it grows exponentially. Thus, after a period of 10-15 years, this causes the scientific literature to double (Figure 2).

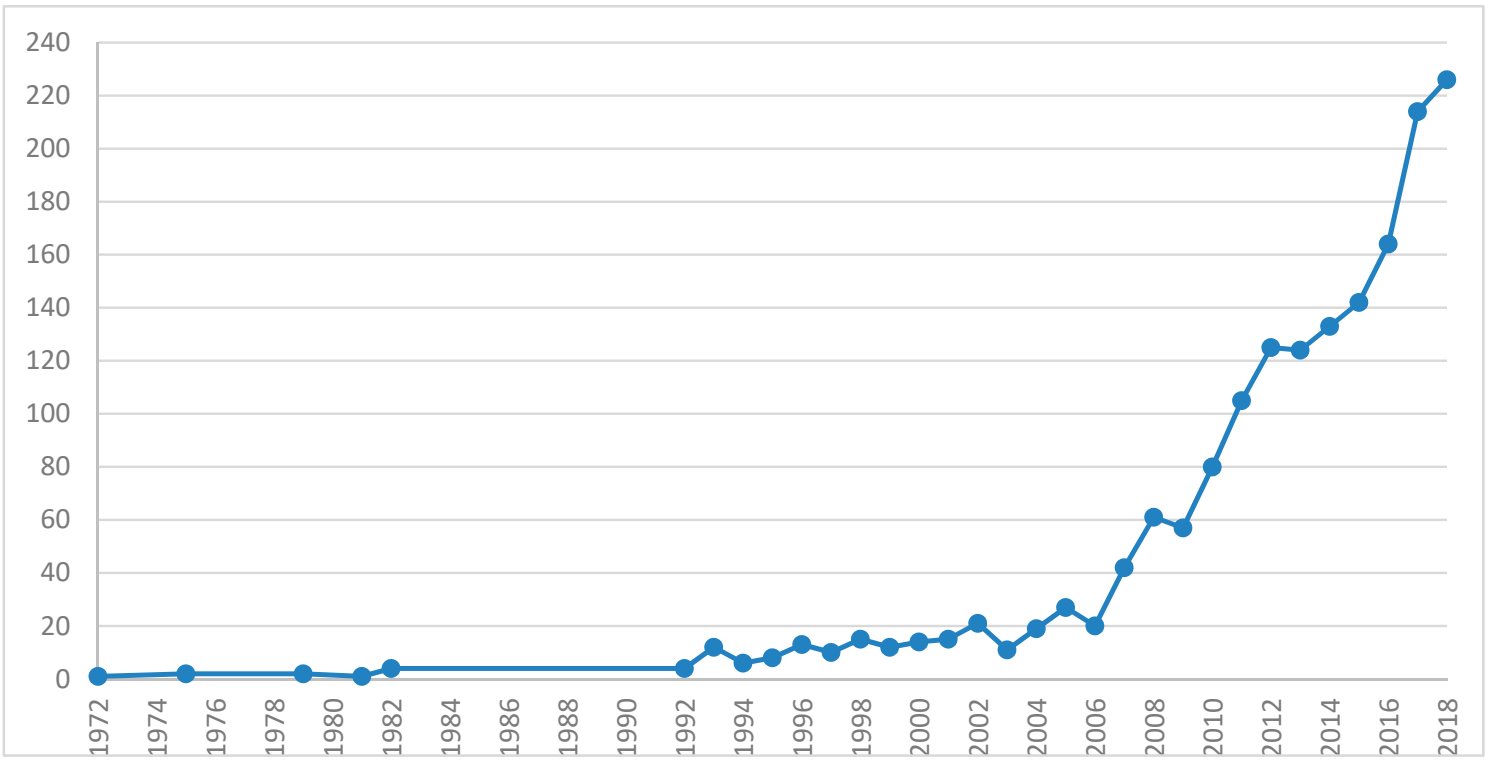

Figure 2. Price's law. Note: own production.

This graph corroborates Price's law, since in a period of 10 years (2008-2018), publications have increased in number from 61 (2008) to 226 (2018). In addition, this figure shows that the trend in this respect is upwards. 


\subsection{Characteristics of Publications and Dispersion of Production}

Taking into consideration the different types of scientific documents, this block shows the distribution of the types of publications. The following figure (Figure 3) shows that the great majority of publications were scientific articles, making up $93.6 \%$ of the total publications, followed by reviews $(5.1 \%)$. The remaining minority groups made up percentages that did not exceed $5 \%$ and were, therefore, not representative of publications in this field.

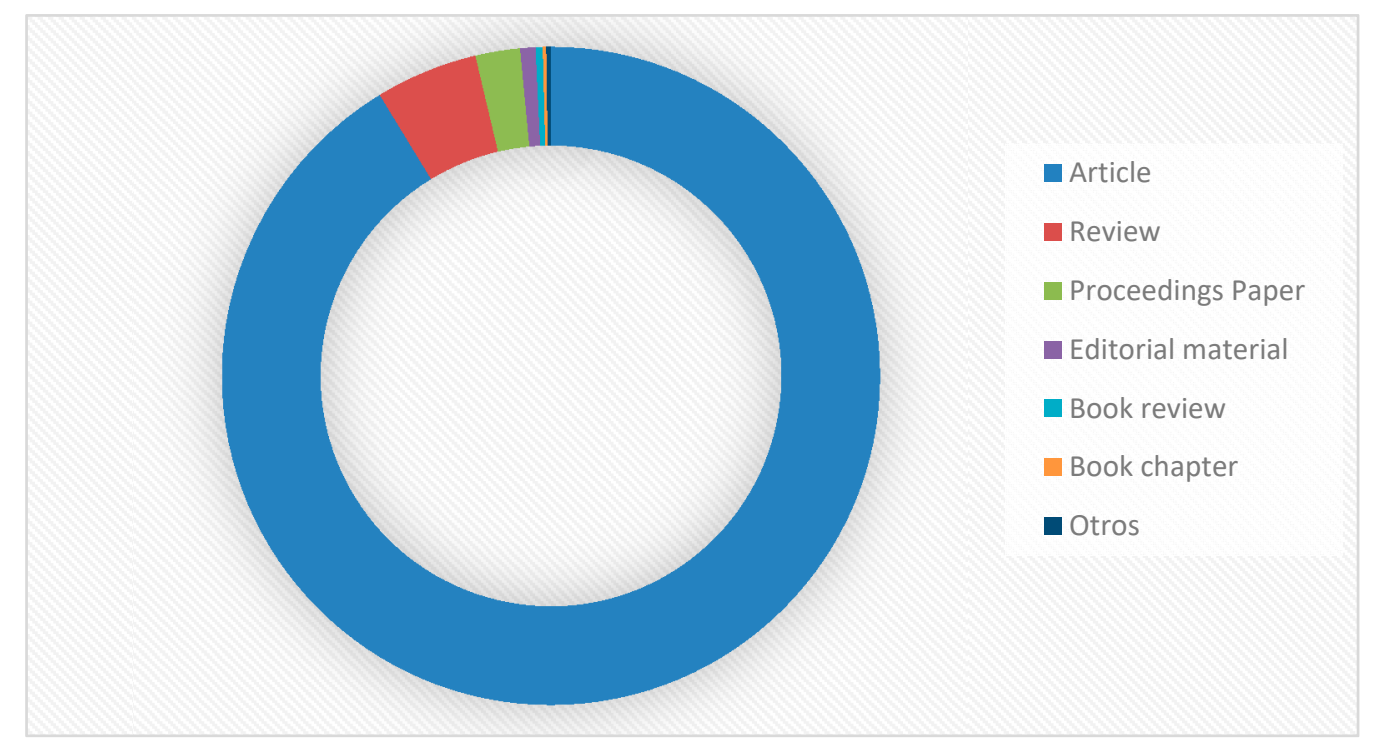

Figure 3. Classification of scientific documents on educational technology and higher education. Note: own production.

In this block, moreover, we find another bibliometric law. Bradford's Law, also known as the law of dispersion of scientific literature, indicates that a small number of journals concentrate a large number of publications, just as larger groups of journals have a very similar number of publications. What this law tries to demonstrate is that the distribution of the production of articles referring to one subject is highly unequal $[29,30]$. Figure 4 shows how different publications were grouped into several zones (zone 1, zone 2) that each include the same or a similar number of publications as the core publication area. The total consisted of 656 journals that include 1689 publications, distributed in three zones with an average of 550 publications in each. The nucleus zone was comprised of only 19 journals with 546 publications (32.32\% of the total) - with number of publications being similar to those in the other zones. 


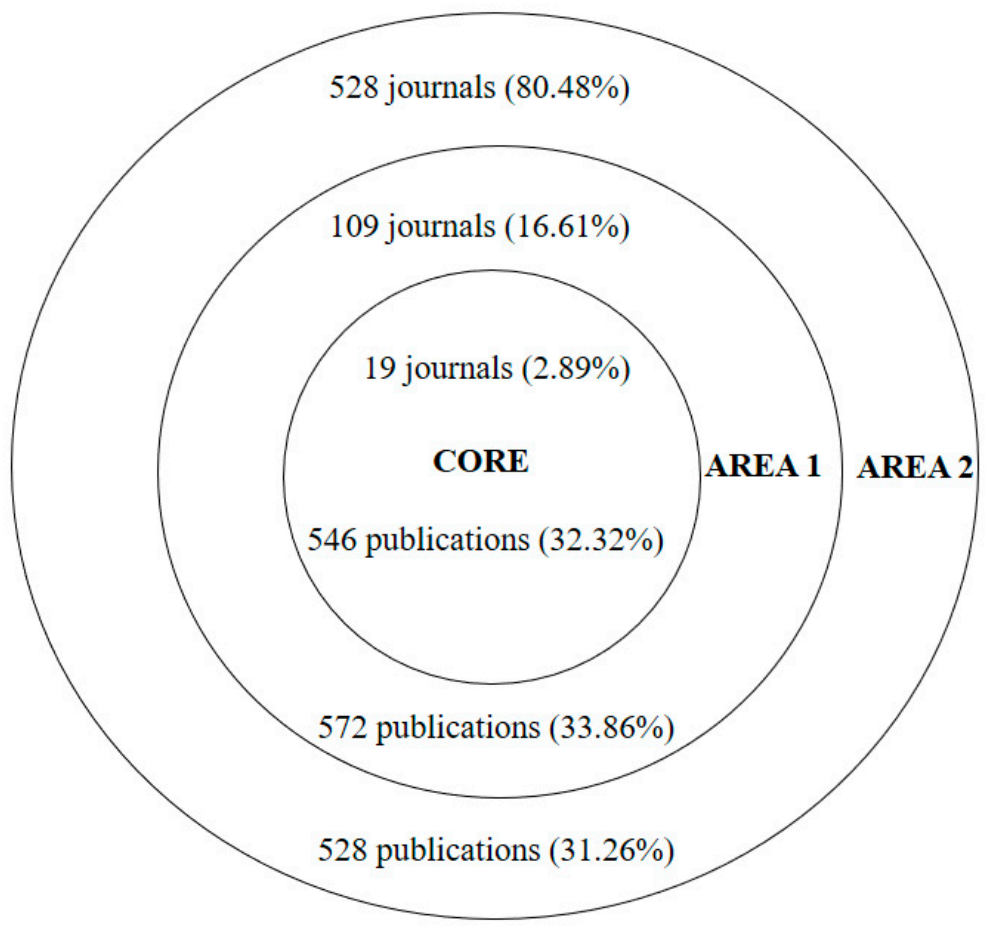

Figure 4. Dispersal area of scientific journals on educational technology in higher education based on Bradford's Law. Note: own production.

It has already been found that all these documents, mostly articles, are usually contained in a few journals. Below are the 10 most productive journals, i.e., those that produce a significant number of publications. Figure 5 shows that these 10 journals, which represent $1.51 \%$ of the total found in the Web of Science with our keywords, contained a total of 390 publications, that is, $23.09 \%$ of the total. The two journals with the most articles on this subject were Computers Education (115) and the British Journal of Educational Technology (51). The other eight journals in Figure 5 do not show a great difference in the numbers of articles published, as was observed between the first and second journals. Rather the number of publications by these journals are similar, albeit progressively decreasing.

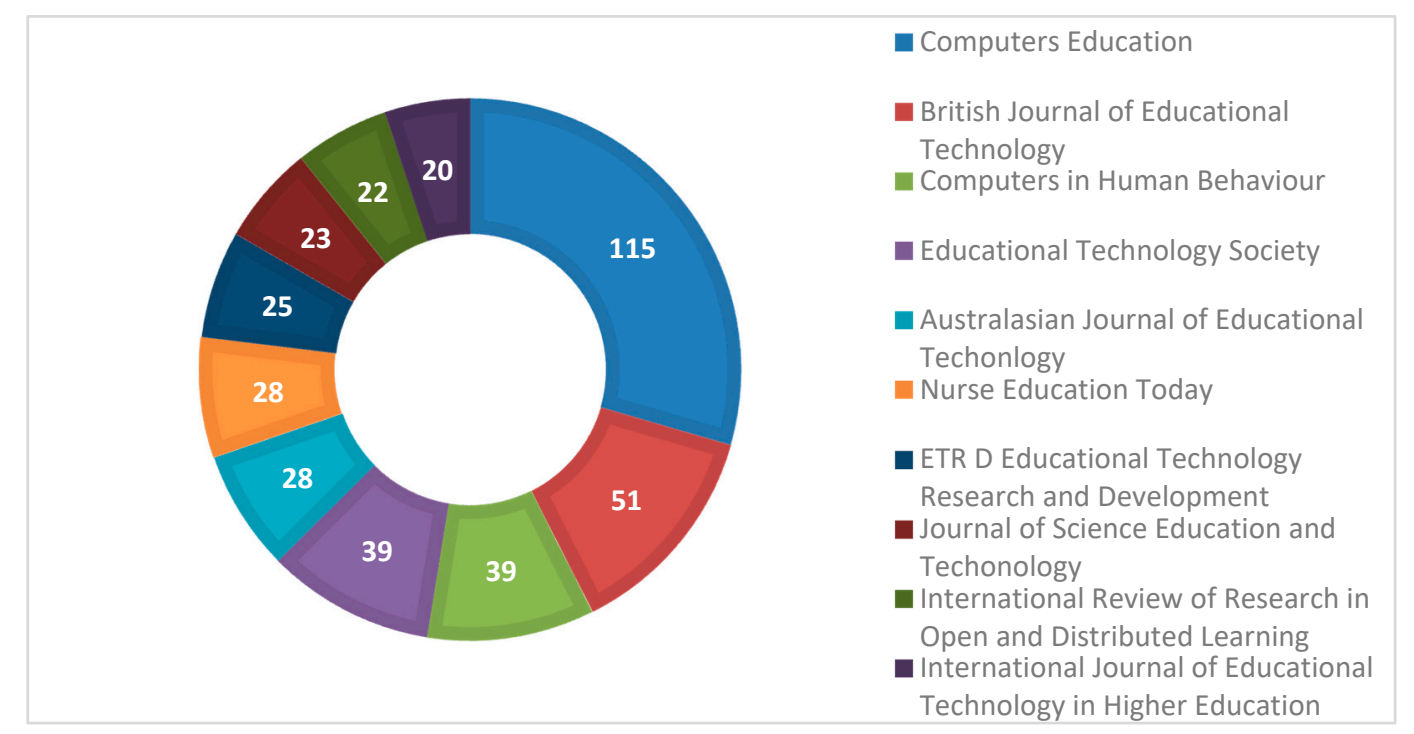

Figure 5. The most productive journals in the field of technology in higher education. Note: own production. 


\subsection{Productivity of Authors and Institutions}

Below is a series of impact indicators divided into factors in order to determine the level of influence of educational technology within the higher education stage with a greater level of precision. In the first place, the 10 most prolific authors are presented (Table 3) - that is, those who have the greatest scientific production in this field of study. The author with the highest productivity is Tsai, with eight contributions to the subject, followed by Hwang (seven), Kirkwood (six), and Kloss (six). In contrast, it should be specified that although they were the ones with the greatest number of publications, these authors were not those with the greatest impact indices. In this case, we found that Selwyn $(I=49.2)$ had the highest impact index followed by Price $(I=43.6)$.

Table 3. Authors with the highest number of contributions in higher education and educational technology.

\begin{tabular}{cccccl}
\hline Author & No. Doc & \% & Citations & Impact Index & \multicolumn{1}{c}{ University } \\
\hline Tsai C.C. & 8 & 0.473 & 110 & 13.75 & National Taiwan University of Education \\
Hwang G.J. & 7 & 0.414 & 177 & 25.28 & National Taiwan University of Education \\
Kirkwood A. & 6 & 0.355 & 262 & 43.66 & Open University UK \\
Kloos C.D. & 6 & 0.355 & 165 & 27.5 & Universidad Carlos III de Madrid \\
Bennetts S. & 5 & 0.296 & 259 & 43.16 & University of Wollongong \\
Chen Y.L. & 5 & 0.296 & 53 & 10.6 & Aletheia University \\
Hernández-Leo D. & 5 & 0.296 & 41 & 8.2 & Universidad Pompeu Fabra \\
Liang J.C. & 5 & 0.296 & 32 & 6.4 & National Taiwan University of Science Technology \\
Price L. & 5 & 0.296 & 233 & 46.6 & Open University UK \\
Selwyn N. & 5 & 0.296 & 246 & 49.2 & Monash University \\
\hline
\end{tabular}

If we look at the institutions that stand out in terms of the greatest scientific production (Table 4), we see that the University of California with 34 documents occupies first place, followed by the University of Florida with 23 and the University of Georgia with 22. In general terms, North American universities (University of California, University of Florida, Pennsylvania Commonwealth System of Higher Education (PCSHE), University System of Georgia, Harvard University, etc.) have produced almost all of the published documents on educational technology and higher education.

Table 4. Institutions with the highest number of contributions in higher education and educational technology.

\begin{tabular}{ccccc}
\hline Institutions & No.Doc & \% & Citations & Impact Index \\
\hline University of California System & 34 & 2.014 & 639 & 18.79 \\
State University System of Florida & 24 & 1.422 & 309 & 12.875 \\
(PCSHE) & 23 & 1.363 & 369 & 16.043 \\
Pennsylvania Commonwealth System of Higher Education & 22 & 1.303 & 540 & 24.545 \\
University System of Georgia & 21 & 1.244 & 377 & 17.952 \\
Harvard University & 20 & 1.185 & 202 & 10.1 \\
University of London & 20 & 1.185 & 506 & 2.3 \\
University of Texas System & 16 & 0.948 & 250 & 15.625 \\
Indiana University System & 14 & 0.829 & 392 & 28 \\
Open University UK & 14 & 0.829 & 369 & 26.357 \\
\hline
\end{tabular}

Note: own production.

On the other hand, focusing on the level of impact of the publications of these institutions, it was found that observed that the University of Indiana followed very closely by the Open University of the United Kingdom stand out considerably.

Finally, VOSviewer software was used to create network maps containing keyword nodes of all the articles in the sample. A network map was made to illustrate the connections between descriptors of the different publications and the number of times that a keyword was used. The larger the keyword, the more times it was used, and vice versa. 
In this way, Figure 6 verifies, by means of the colors, that a total of six groups or clusters existed that interrelated among themselves and formed intermediate colors. The keywords most used as descriptors were "technology", followed by "higher education" and "students".

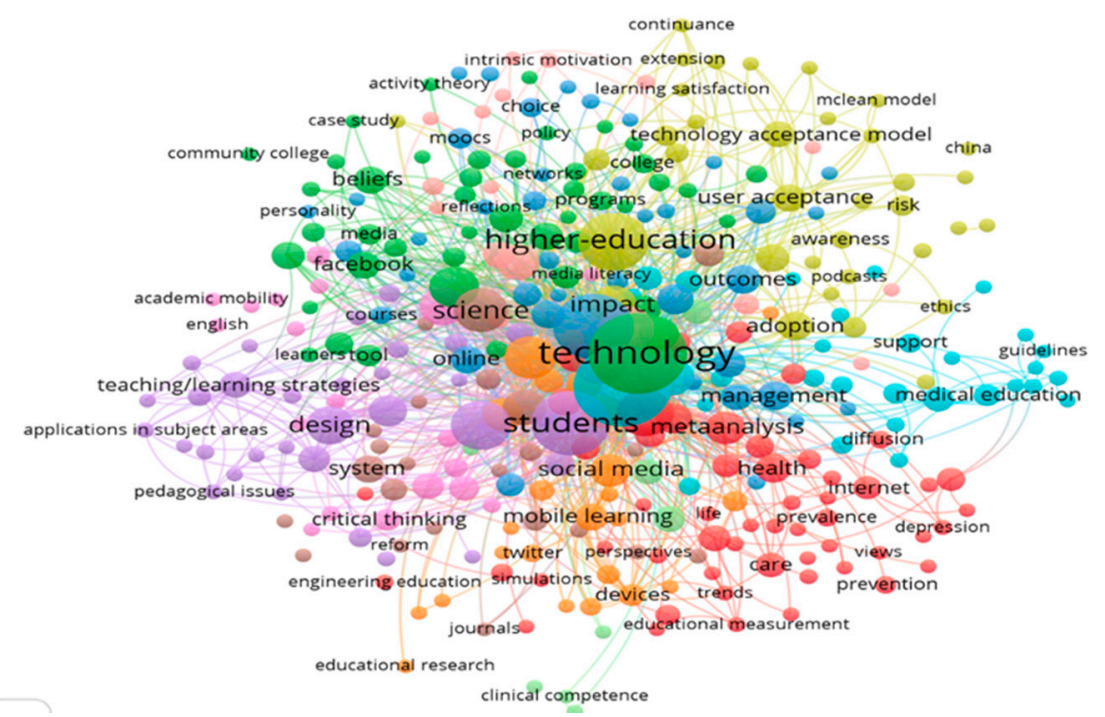

Figure 6. Connection map between keywords. Note: own production.

\section{Discussion}

This research facilitates the elucidation of everything related to scientific production on educational technology and higher education. Since the first publications in this field of study in 1972, there have been a total of 1689 publications over the years, with the number of publications experiencing a growth in the last 20 years that reaches its peak today. This ever-increasing growth in literature on this subject is fundamentally due to the growing presence of technology in all spheres of society and, of course, in the classroom. In this way, and following [2], we can observe how different studies have been carried out over the last few years and can verify the benefits and elements they provide. This, in turn, has led to further research on the subject, to the point where such research can be consolidated as a reference subject in educational research.

In this line of research on technology in the field of education, there have been quite a few studies that focus both on the perceptions of teachers and learners, such as those carried out by [11,13]. In all articles on this subject, there is usually a common pattern: teachers are generally reluctant to implement technologies in the classroom, while students are more positive and interested in employing technology. At the same time, these and other studies emphasize the need to identify the methods of teaching with and through technologies in the most appropriate way possible, wherein the use of technology is not limited to the mere handling of multimedia devices, but it is employed an effective tool in T-L processes to benefits all its members, as stated by [2,23], among others.

With regard to the types of documents most frequently published on the subject, it can be seen that the "article" category that dominated the others with a majority of more than $90 \%$ of the total number of publications. The other categories did not have significant enough representation to be able to affirm that they play an important role in the literature on this subject. These findings corroborate the idea that the current era in educational research is mainly centered on the production of scientific articles due to their impact and relevance within the scientific community. Thus, it is expected that the number of publications of this type will increase in the future, as has been the trend has been for several years. In addition, it is necessary to emphasize that, although the two main agents in the T-L process are teachers and students, the latter are the majority group chosen as a focus by researchers in this field of study. This was illustrated by the key descriptors in the bibliometric map, indicating that 
most studies on this subject consider the training of the student and, possibly, the future teacher, rather than the training of the current teacher.

\section{Conclusions}

The aim of this work was to demonstrate that technology is not only a subject already present in all areas of education, but it is also a changing element that has come to stay. Therefore, constant research and innovation in this field of study is necessary for the correct development of T-L as a whole, and in this area in particular. As this study reveals, a boom was observed in this field of knowledge in the last two decades, owing to the popularity and omnipresence of this element in daily life. This has led to a rethinking of all the models, methodologies, materials, etc. used to date, which has led to the proliferation of scientific publications featuring technology as their main focus and the educational field as their context.

Higher education is an essential stage in the formation of future professionals in any field, but it is even more important when those future professionals are going to be teachers, because they will also educate new generations of future professionals. Thus, the initial formation they receive during their higher education must be adequate to meet the current needs of the society and to educate the students they will have. In this way, technology and higher education not only must go hand in hand, but they should also serve as a model for other educational stages and members of the educational community in order to extract theoretical and practical knowledge, among other things.

This model relation between technology and education is what inspired this article, with the aim of offering a vision that clarifies the current state of the scientific literature on this subject and how it evolved to its present state.

Author Contributions: C.R.J. and S.A.G.; methodology, C.R.J.; software, M.S.P.; formal analysis, S.A.G.; investigation, C.R.J., S.A.G., and M.S.P.; writing-original draft preparation, C.R.J., and S.A.G.; writing—review and editing, S.A.G., and M.S.P.; visualization, M.S.P.; supervision, S.A.G.

Funding: This research received no external funding.

Acknowledgments: We acknowledge the researchers of the research group AREA (HUM-672), which belongs to the Ministry of Education and Science of the Junta de Andalucía and is based in the Department of Didactics and the School Organization of the Faculty of Education Sciences of the University of Granada.

Conflicts of Interest: The authors declare no conflict of interest.

\section{References}

1. Hamid, S.; Waycott, J.; Kurnia, S.; Chang, S. Understanding students' perceptions of the benefits of online social networking use for teaching and learning. Internet High Educ. 2015, 26, 1-9. [CrossRef]

2. Mayes, R.; Natividad, G.; Spector, J. Challenges for educational technologists in the 21st century. Educ. Sci. 2015, 5, 221-237. [CrossRef]

3. Su, C.; Cheng, C. A mobile gamification learning system for improving the learning motivation and achievements. J. Comput. Assist. Learn. 2015, 31, 268-286. [CrossRef]

4. Broadbent, J.; Poon, W. Self-regulated learning strategies academic achievement in online higher education learning environments: A systematic review. Internet High Educ. 2015, 27, 1-13. [CrossRef]

5. Hao, Y.; Lee, K.S. Teaching in flipped classrooms: Exploring pre-service teachers' concerns. Comput. Hum. Behav. 2016, 57, 250-260. [CrossRef]

6. Instefjord, E.J.; Munthe, E. Educating digitally competent teachers: A study of integration of professional digital competence in teacher education. Teach. Teach. Educ. 2017, 67, 37-45. [CrossRef]

7. Bayne, S. What's the matter with 'technology-enhanced learning'? Learn. Media Technol. 2015, 40, 5-20. [CrossRef]

8. Tondeur, J.; Aesaert, K.; Prestridge, S.; Consuegra, E. A multilevel analysis of what matters in the training of pre-service teacher's ICT competencies. Comput Educ. 2018, 122, 32-42. [CrossRef]

9. Fernández-Cruz, F.; Fernández-Díaz, M. Teachers generation Z and their digital skills. Comunicar 2016, 46, 97-105. [CrossRef] 
10. Grande, M.; Cañon, R.; Cantón, I. Tecnologías de la información y la comunicación: Evolución del concepto y características. IJERI 2016, 6, 218-230.

11. Henderson, M.; Selwyn, N.; Aston, R. What works and why? student perceptions of 'useful'digital technology in university teaching and learning. Stud. High. Educ. 2017, 42, 1567-1579. [CrossRef]

12. Chen, F.; Gorbunova, N.V.; Masalimova, A.R.; Bírová, J. Formation of ICT-competence of future university school teachers. EURASIA J. Math. Sci. Technol. Educ. 2017, 13, 4765-4777. [CrossRef]

13. Bartolomé, A.; Castañeda, L.; Adell, J. Personalisation in educational technology: The absence of underlying pedagogies. Int. J. Educ. Technol. Higher Educ. 2018, 15, 14. [CrossRef]

14. Englund, C.; Olofsson, A.D.; Price, L. Teaching with technology in higher education: Understanding conceptual change and development in practice. Higher Educ. Res. Dev. 2017, 36, 73-87. [CrossRef]

15. Akçayır, M.; Akçayır, G. Advantages and challenges associated with augmented reality for education: A systematic review of the literature. Educ. Res. Rev. 2017, 20, 1-11. [CrossRef]

16. Heradio, R.; de la Torre, L.; Galan, D.; Cabrerizo, F.J.; Herrera-Viedma, E.; Dormido, S. Virtual and remote labs in education: A bibliometric analysis. Comput. Educ. 2016, 98, 14-38. [CrossRef]

17. Batanero, J.M.; Rebollo, M.M.; Rueda, M. Impact of ICT on students with high abilities. bibliographic review (2008-2018). Comput. Educ. 2019, 137, 48-58. [CrossRef]

18. Fombona, J.; Pascual-Sevillano, M.A.; Gonzalez-Videgaray, M. M-learning and Augmented Reality: A Review of the Scientific Literature on the WoS Repository. Comunicar 2017, 52, 63-71. [CrossRef]

19. Lorenzo, G.; Scagliarini-Galiano, C. Revisión bibliométrica sobre la realidad aumentada en educación. Revista General de Información y Documentación 2018, 28, 45-60. [CrossRef]

20. Bond, M.; Zawacki-Richter, O.; Nichols, M. Revisiting five decades of educational technology research: A content and authorship analysis of the british journal of educational technology. Br. J. Educ. Technol. 2019, 50, 12-63. [CrossRef]

21. Martin, S.; López-Martín, E.; Lopez-Rey, A.; Cubillo, J.; Moreno-Pulido, A.; Castro, M. Analysis of new technology trends in education: 2010-2015. IEEE Access 2018, 6, 36840-36848. [CrossRef]

22. Fernández-Cano, A.; Bueno, A. Synthesizing scientometric paterns in Spanish educational research. Scientometrics 1999, 46, 349-367. [CrossRef]

23. Rodríguez, A.M.; Trujillo, J.M.; Sánchez, J. Impacto de la productividad científica sobre competencia digital de los futuros docentes: Aproximación bibliométrica en Scopus y Web of Science. Revista Complutense de Educación 2019, 30, 626-646. [CrossRef]

24. Diem, A.; Wolter, S. The use of bibliometrics to measure research performance in education sciences. Res. High Educ. 2013, 54, 86-114. [CrossRef]

25. Aznar Díaz, I.; Trujillo Torres, J.M.; Romero Rodríguez, J.M. Estudio bibliométrico sobre la realidad virtual aplicada a la neurorrehabilitación y su influencia en la literatura científica. Revista Cubana De Información en Ciencias de la Salud 2018, 29, 1-10.

26. Gutiérrez, C.; Martín, A.; Salmerón-Casasempere, A.; Fernández, A. Análisis temático de la investigación educativa soportada por Grounded Theroy. Bordón 2017, 69, 83-102. [CrossRef]

27. Rodríguez, A.M.; Romero, J.M.; Agreda, M. Impact of ICT on the teaching of physical education: A bibliometric research study. Educ. Sport Health Phys. Act. 2019, 3, 1-14.

28. Price, D.J.S. Little Science, Big Science ... and Beyond; Columbia University Press: New York, NY, USA, 1986.

29. Bradford, S.C. Sources of Information on Specific Subjects. J. Inf. Sci. 1934, 10, 173-180. [CrossRef]

30. Miranda, A. Bibliometría. Bibliotecas 1990, 8, 1-11.

(C) 2019 by the authors. Licensee MDPI, Basel, Switzerland. This article is an open access article distributed under the terms and conditions of the Creative Commons Attribution (CC BY) license (http://creativecommons.org/licenses/by/4.0/). 